\title{
New generation protein supplement in combined feeds for broiler chickens
}

\author{
E.N. Andrianova*, and I. A. Egorov \\ Federal Scientific Center All-Russian Research and Technological Poultry Institute RAS, 10 \\ Ptitsegradskaya Str., 141311 Sergiev Posad, Moscow region, Russia
}

\begin{abstract}
In experiments on broiler chickens of the SGC "Smena" selection, it was found that the partial replacement of fish meal with an additive based on a protein of microbial origin, containing $68.3 \%$ of crude protein, allows to provide a live weight of chickens comparable to the control with high poultry safety, due to good protein digestibility and availability of amino acids. A comprehensive assessment of the productivity of broilers according to the productivity index showed that the replacement of $50 \%$ of fish meal with microbial protein contributed to an increase in the productivity index of chickens of the second group by 4.78 points in comparison with the control. The complete replacement of fish meal in the third experimental group was less effective, as evidenced by a decrease in the productivity index to 303.91 points compared to 308.73 in the control. It is shown that the introduction of a protein supplement into the feed for broiler chickens in Analysis of the chemical composition of the liver of 35-day-old broilers showed that the protein content in the liver of chickens of the second and third groups was higher than the control by 1.99 and $0.58 \%$, while there was no increase in the fat content in the groups with a protein supplement. The crude fat content was at the level of 11.38 and $12.20 \%$ versus $13.0 \%$ in the control, which indirectly indicates the absence of a cytotoxic effect on liver cells from the use of microbial protein in the studied dosages.
\end{abstract}

\section{Introduction}

Use in feed production of protein sources based on non-traditional feed means, such as lowalkaloid lupine, rapeseed, peas, etc. $[1,2,3,4]$ allows for reducing the use of soybeans and products of its processing in poultry rations, to reduce the inclusion of animal feed in compound feeds $[5,6]$. Protein products obtained with the use of improved technologies of microbiological synthesis $[6,7,8,9]$, which replaced traditional technologies that allowed the production of microbial protein from hydrocarbon raw materials, are also worth noticing. Despite the high production volumes of paprine, eprin and haprin for the needs of agriculture in the $90 \mathrm{~s}$, the industrial production of microbial protein obtained from hydrocarbon raw materials at Russian biochemical plants was stopped due to the negative impact on the environment due to imperfect purification technologies, which led to

\footnotetext{
*Corresponding author: andrianova@vnitip.ru
} 
pollution of the environment and atmosphere with protein dust and cells of producer microorganisms. Currently, the production in Russia of haprin, meprin and eprin using traditional technologies is practically absent, and from the products of microbiological synthesis, the feed industry mainly uses fodder yeast, which is obtained by the microbiological method on various nutrient media from the waste of timber processing sulfite-cellulose and alcohol production [9].

The purpose of these studies was to study the possibility of using a functional protein supplement obtained from plant resources based on microbiological synthesis technologies to replace animal feed in compound feed for broiler chickens.

\section{Materials and methods}

To accomplish this task, an experiment was carried out on broiler chickens of the SGC "Smena" selection from one day old to 35-day-old in the vivarium of the SGC "Zagorskoye", Federal Scientific Center All-Russian Research and Technological Poultry Institute RAS. Broilers were kept in a R-15 cage battery. The groups were formed by the method of analogs by live weight without division by sex, 35 animals per group. Chickens received dry full-feed loose mixed feed with nutritional value according to the standards of Federal Scientific Center All-Russian Research and Technological Poultry Institute 2019, ad libitum, according to the scheme shown in Table 1.

Table 1. Scheme of the broilers experiment.

\begin{tabular}{|l|l|}
\hline Group & \multicolumn{1}{|c|}{ Feed characteristic } \\
\hline 1 (c) & Nutrient-balanced compound feed containing fish meal \\
\hline 2 & $\begin{array}{l}\text { Compound feed, balanced in all nutrients, replacing 50\% of fish meal with } \\
\text { protein supplement during the entire growing period }\end{array}$ \\
\hline 3 & $\begin{array}{l}\text { Compound feed, balanced in all nutrients, with replacement of 50\% of fish } \\
\text { meal with protein supplement from 3-21 days and 100\% replacement of } \\
\text { fish meal from 22 to 35 days of growing }\end{array}$ \\
\hline
\end{tabular}

Table 2. Composition and nutritional value of compound feed for broiler chickens, $\%$.

\begin{tabular}{|c|c|c|c|c|c|c|}
\hline \multirow{3}{*}{ Constituent } & \multicolumn{6}{|c|}{ Group } \\
\hline & \multicolumn{3}{|c|}{ 3-21 days } & \multicolumn{3}{|c|}{ 22-34 days } \\
\hline & $1 \mathrm{c}$ & 2 & 3 & $1 \mathrm{c}$ & 2 & 3 \\
\hline wheat & 53.1 & 52.7 & 52.7 & 55.7 & 53.4 & 53.0 \\
\hline full-fat soya beans & 10.0 & 10.0 & 10.0 & 25.0 & 27.0 & 27.0 \\
\hline soybean meal SP $42 \%$ & 18.0 & 18.0 & 18.0 & - & - & - \\
\hline sunflower meal SP 36\% & 5.0 & 5.0 & 5.0 & 8.0 & 8.0 & 8.0 \\
\hline corn gluten & 2.0 & 2.0 & 2.0 & - & - & - \\
\hline fish meal SP $67 \%$ & 4.0 & 2.0 & 2.0 & 4.0 & 2.0 & - \\
\hline Protein supplement & - & 2.0 & 2.0 & - & 2.0 & 4.0 \\
\hline soybean oil & 4.7 & 4.7 & 4.7 & 4.0 & 4.0 & 4.0 \\
\hline lysine monochlorohydrate & 0.27 & 0.31 & 0.31 & 0.30 & 0.30 & 0.35 \\
\hline DL-methionine & 0.26 & 0.26 & 0.26 & 0.25 & 0.25 & 0.27 \\
\hline fine salt & 0.30 & 0.33 & 0.33 & 0.30 & 0.33 & 0.36 \\
\hline monocalcium phosphate & 0.7 & 0.8 & 0.8 & 0.8 & 0.90 & 1.0 \\
\hline limestone flour & 1.3 & 1.5 & 1.5 & 1.3 & 1.5 & 1.70 \\
\hline premix & 0.35 & 0.35 & 0.35 & 0.35 & 0.35 & 0.35 \\
\hline \multicolumn{7}{|c|}{$100 \mathrm{~g}$ of compound feed contains: } \\
\hline $\begin{array}{l}\text { Available energy, kcal } \\
\mathrm{MJ} / \mathrm{kg}\end{array}$ & $\begin{array}{c}308 \\
12.89 \\
\end{array}$ & $\begin{array}{c}307 \\
12.84 \\
\end{array}$ & $\begin{array}{c}307 \\
12.84 \\
\end{array}$ & $\begin{array}{c}318 \\
13.31 \\
\end{array}$ & $\begin{array}{c}318 \\
13.31 \\
\end{array}$ & $\begin{array}{c}317 \\
13.26 \\
\end{array}$ \\
\hline Crude protein & 23.49 & 23.51 & 23.51 & 21.64 & 22.14 & 22.18 \\
\hline
\end{tabular}


Table 2. Continued.

\begin{tabular}{|l|c|c|c|c|c|c|}
\hline Crude fat & 8.09 & 8.01 & 8.01 & 9.94 & 10.20 & 10.11 \\
\hline Linoleic acid & 3.97 & 3.96 & 3.96 & 4.94 & 5.09 & 5.08 \\
\hline Crude fiber & 4.32 & 4.42 & 4.42 & 4.24 & 4.39 & 4.49 \\
\hline Lysine & 1.36 & 1.36 & 1.36 & 1.25 & 1.25 & 1.25 \\
\hline Methionine & 0.64 & 0.63 & 0.63 & 0.60 & 0.59 & 0.59 \\
\hline Methionine + cystine & 0.98 & 0.97 & 0.97 & 0.90 & 0.90 & 0.90 \\
\hline Assimilable lysine & 1.21 & 1.19 & 1.19 & 1.10 & 1.09 & 1.08 \\
\hline Assimilable methionine & 0.59 & 0.57 & 0.57 & 0.54 & 0.53 & 0.53 \\
\hline Methionine + assimilable cystine & 0.87 & 0.85 & 0.85 & 0.77 & 0.77 & 0.77 \\
\hline Calcium & 0.91 & 0.92 & 0.92 & 0.90 & 0.91 & 0.92 \\
\hline Phosphorus & 0.67 & 0.66 & 0.66 & 0.69 & 0.69 & 0.69 \\
\hline Available phosphorus & 0.40 & 0.40 & 0.40 & 0.41 & 0.41 & 0.41 \\
\hline Potassium & 0.82 & 0.82 & 0.82 & 0.73 & 0.75 & 0.74 \\
\hline Sodium & 0.17 & 0.17 & 0.17 & 0.17 & 0.17 & 0.16 \\
\hline Cl & 0.30 & 0.31 & 0.31 & 0.3 & 0.31 & 0.32 \\
\hline
\end{tabular}

During the first three days, broilers of all groups received pre-starter compound feed in the form of granules with a particle diameter of 0.9 to $1.2 \mathrm{~mm}$ of the same nutritional value.

Balance experiments to determine the digestibility and availability of nutrients in the diet were also carried out on males ( $\mathrm{n}=3$ from each group) at 30-33 days.

The mean values $(M)$ and mean errors $( \pm \mathrm{m})$ were calculated for the indicators of counting and measurements. The significance of differences was assessed by Student's $t$ test, the differences were considered significant at $\mathrm{P} \leq 0.05$. The analysis of the chemical and amino acid composition of the protein product, feed and litter, calcium and phosphorus in the tibia of broilers at the end of the experiment was carried out by specialists of the Department of Physiology and Biochemical Analysis of the Federal Research Center "Federal Scientific Center All-Russian Research and Technological Poultry Institute" RAS.

\section{Results and discussion}

The investigated additive is a fodder protein mixture of fermentolysate of plant raw materials and biomass of lactic acid and propionic acid bacteria, obtained as a result of bioconversion using non-pathogenic strains of a consortium of microorganisms. Its chemical and amino acid composition is shown in Table 3.

Due to the high content of non-protein nitrogen in the product $-3.41 \%$, the complete replacement of fish meal for broilers of the third group was carried out in the final growing period.

Table 3. Chemical and amino acid composition of the protein supplement ( $\%$ on air-dry basis).

\begin{tabular}{|l|c|c|}
\hline \multicolumn{1}{|c|}{ Indicator } & Protein supplement & Fish meal (tabular data) \\
\hline Crude protein & $\mathbf{6 8 . 3}$ & $\mathbf{6 7 . 0}$ \\
\hline Non-protein nitrogen & $\mathbf{3 . 4 1}$ & - \\
\hline Crude ash & 5.90 & 14.0 \\
\hline Fat & 3.35 & 7.4 \\
\hline Calcium & 0.33 & 4.26 \\
\hline Phosphorus & 1.44 & 2.5 \\
\hline aspartic acid & 6.52 & 6.0 \\
\hline threonine & 3.1 & 2.81 \\
\hline Serine & 2.19 & 2.86 \\
\hline glutamic acid & 6.41 & 9.1 \\
\hline Proline & 3.21 & 3.17 \\
\hline glycine & 3.64 & 4.54 \\
\hline Alanine & 4.82 & 3.93 \\
\hline Valin & 4.45 & 3.67
\end{tabular}


Table 3. Continued.

\begin{tabular}{|l|c|c|}
\hline Isoleucine & 3.23 & 2.83 \\
\hline Leucine & 5.11 & 4.65 \\
\hline Tyrosine & 2.64 & 2.0 \\
\hline Phenylalanine & 3.47 & 2.80 \\
\hline Histidine & 1.08 & 1.44 \\
\hline Lysine & 3.49 & 5.11 \\
\hline Arginine & 3.31 & 3.89 \\
\hline Cystine & 0.41 & 0.62 \\
\hline Methionine & 1.63 & 1.88 \\
\hline
\end{tabular}

The results of the experiment (Table 4) showed that at 14 days of age the live weight of the chickens of the second and third experimental groups, which received microbial protein instead of $50 \%$ fish meal, was higher than the control by 4.16 and $3.98 \%$ (the difference is significant at $\mathrm{P} \leq 0.05$ ), at 21 days of age the advantage of the experimental groups in terms of live weight in comparison with the control was 1.06 and $0.71 \%$ (the difference is unreliable).

In the final period of rearing, the chickens of the second experimental group, which received $50 \%$ ( $2 \%$ by weight of the compound feed) protein supplement instead of fish meal, retained a higher growth rate in comparison with the control poultry. The live weight of the chickens in this group was $1.3 \%$ higher than the control (the difference is not statistically significant). Furthermore, the live weight of the males was $2.4 \%$ higher than that of the control, and the females - by $0.5 \%$. The use of a protein supplement contributed to a decrease in feed costs per $1 \mathrm{~kg}$ of live weight gain by $0.17 \%$ in comparison with the control.

Complete replacement of fish meal with an additive in mixed feed for chickens of the third experimental group in the final period of growing provided a live weight of chickens comparable to the control, however, the backlog in live weight of males of the third group from the control was $1.2 \%$, and that of females $-1.4 \%$ (the difference is not reliable). The feed conversion also deteriorated by $1.36 \%$.

There were no significant differences in the viability of poultry in the studied groups. The safety of the flock in all groups at the end of cultivation was high and amounted to $100 \%$.

A comprehensive assessment of the productivity of broilers according to the productivity index showed that replacing $50 \%$ of fish meal with an additive made it possible to increase the productivity index of chickens of the second group by 4.78 points in comparison with the control. The complete replacement of fish meal in the third experimental group was less effective, as evidenced by a decrease in the productivity index to 303.91 points compared to 308.73 in the control.

Table 4. Productivity of broiler chickens at different levels of feed additive inclusion \pm .

\begin{tabular}{|c|c|c|c|}
\hline \multirow{2}{*}{ Indicator } & \multicolumn{3}{|c|}{ Group } \\
\hline & $1(\mathrm{c})$ & 2 & 3 \\
\hline Flock safety, $\%$ & 100 & 100 & 100 \\
\hline $\begin{array}{l}\text { Live weight, } g \text { at the age, days: } \\
7\end{array}$ & $164.7 \pm 1.1$ & $164.8 \pm 1.2$ & $165.1 \pm 1.0$ \\
\hline 14 & $430.1 \pm 4.4$ & $\begin{array}{c}448.0 \pm 6.2^{*} \\
+4.16 \%\end{array}$ & $\begin{array}{l}447.2 \pm 6.1^{*} \\
++3.98 \%\end{array}$ \\
\hline 21 & $871.30 \pm 12.0$ & $\begin{array}{l}880.5 \pm 10.8 \\
++1.06 \%\end{array}$ & $\begin{array}{l}877.5 \pm 11.4 \\
++0.71 \%\end{array}$ \\
\hline 35 & $1894.80 \pm 33.62$ & $\begin{array}{c}1920.31 \pm 34.23 \\
++1.3 \%\end{array}$ & $\begin{array}{c}1890.72 \pm 30.39 \\
+-0.2 \%\end{array}$ \\
\hline
\end{tabular}


Table 4. Continued.

\begin{tabular}{|c|c|c|c|}
\hline Including & $2062.20 \pm 35.03$ & $\begin{array}{c}2110.93 \pm 31.21 \\
++2.4 \%\end{array}$ & $\begin{array}{c}2036.89 \pm 29.17 \\
+-1.2 \%\end{array}$ \\
female chicks & $1769.25 \pm 30.43$ & $\begin{array}{c}1777.35 \pm 24.92 \\
++0.5 \%\end{array}$ & $\begin{array}{c}1744.56 \pm 20.92 \\
+-1.4 \%\end{array}$ \\
\hline Feed costs per 1 bird, kg & 3.27 & 3.31 & 3.308 \\
\hline Feed costs per 1 kg of live weight gain, kg & 1.765 & 1.762 & 1.789 \\
\hline Average daily gain in live weight, g & 54.49 & 55.24 & 54.37 \\
\hline EPI, point & 308.73 & 313.51 & 303.91 \\
\hline
\end{tabular}

$* \mathrm{P} \leq 0.05$.

The data of the balance experiment presented in Table 3 are consistent with the obtained zootechnical results. Thus, the digestibility of protein, dry matter of feed, fat, the use of nitrogen, calcium, the availability of lysine and methionine were better in broilers of the second experimental group by $0.26 ; 1.72 ; 1.53 ; 1.1$ and $0.7 \%$ compared to control. Fiber digestibility and methionine availability were at the control level.

Table 5. Digestibility and nutrient utilization (\%), broilers aged 30-33 days.

\begin{tabular}{|l|c|c|c|}
\hline \multirow{2}{*}{ Indicator } & \multicolumn{2}{|l|}{ Group } & \multicolumn{2}{|c|}{3} \\
\cline { 2 - 4 } & 1 (c) & 2 & 3 \\
\hline Protein digestibility, & $92.04 \pm 0.47$ & $92.3 \pm 0.51$ & $91.67 \pm 0.42$ \\
\cline { 2 - 4 } dry basis of feed. & $83.76 \pm 0.39$ & $85.48 \pm 0.40$ & $83.37 \pm 0.41$ \\
\cline { 2 - 4 } fat, & $81.8 \pm 0.35$ & $82.9 \pm 0.33$ & $82.0 \pm 0.34$ \\
\cline { 2 - 4 } fiber & $34.3 \pm 0.27$ & $34.5 \pm 0.24$ & $34.1 \pm 0.22$ \\
\hline Use of nitrogen & $55.8 \pm 0.30$ & $56.5 \pm 0.29$ & $54.4 \pm 0.25$ \\
\cline { 2 - 4 } calcium & $60.57 \pm 0.34$ & $62.01 \pm 0.37$ & $60.2 \pm 0.35$ \\
phosphorus & $48.5 \pm 0.30$ & $48.9 \pm 0.29$ & $49.5 \pm 0.25$ \\
\hline Availability of lysine & $91.1 \pm 0.49$ & $90.8 \pm 0.54$ & $87.5 \pm 0.50$ \\
methionine & $91.4 \pm 0.50$ & $91.7 \pm 0.52$ & $91.3 \pm 051$ \\
\hline
\end{tabular}

Complete replacement of fish meal in the final growing period in broilers of the third experimental group led to a slight decrease in protein digestibility, feed nitrogen use and lysine availability - by $0.37 ; 1.4$ and $3.6 \%$. The digestibility of fat, dry matter of feed, fiber, availability of methionine in chickens of the third group was comparable to the control.

There were no significant differences between the groups in terms of the content of crude ash, the deposition of calcium and phosphorus in the skeleton of broilers from the control and experimental groups. The indicators corresponded to the physiological norm and the direction of poultry productivity.

Table 6. Chemical composition (\%) and vitamin content $(\mu \mathrm{g} / \mathrm{g})$ in liver of 35-day-old broilers.

\begin{tabular}{|l|c|c|c|}
\hline \multirow{2}{*}{ Indicator } & \multicolumn{3}{|c|}{ Group } \\
\cline { 2 - 4 } & $1(\mathrm{c})$ & 2 & 3 \\
\hline Moisture & 78.01 & 74.01 & 74.94 \\
\hline Crude ash & 4.85 & 4.92 & 4.90 \\
\hline Crude protein & 71.24 & 73.23 & 71.82 \\
\hline Crude fat & 13.00 & 11.38 & 12.20 \\
\hline Vitamin A & 417.16 & 398.50 & 351.15 \\
\hline Vitamin E & 17.22 & 19.84 & 20.68 \\
\hline Vitamin $\mathrm{B}_{2}$ & 12.98 & 13.25 & 12.92 \\
\hline
\end{tabular}

Analysis of the chemical composition of the liver of 35-day-old broilers showed (Table 4) that the protein content in the liver of chickens of the second and third groups was higher than the control by 1.99 and $0.58 \%$, while there was no increase in the fat content in the groups with a protein supplement. The crude fat content was at the level of 11.38 and 
$12.20 \%$ versus $13.0 \%$ in the control, which indirectly indicates the absence of a cytotoxic effect on liver cells from the use of microbial protein in the studied dosages.

In terms of the storage of vitamin $\mathrm{E}$ in the liver, the chickens of the second and third experimental groups exceeded the control by 15.21 and $20.09 \%$ (the difference is significant), the content of vitamin B2 was at the control level. In the liver of chickens of the third experimental group, a significant deterioration in the deposition of vitamin A by $18.8 \%$ was noted.

Poultry meat is mainly a protein food and one of the important sources of fat in the body.

Analysis of the chemical and amino acid composition of the meat of experimental broilers showed (Table 5) that partial or complete replacement of fish meal with an additive based on microbial protein in the feed of chickens of the second and third experimental groups could not fully compensate for the protein of fish meal. The meat of the experienced broilers in terms of protein content was inferior to the control by 4.57 and $5.07 \%$. The content of non-essential and essential amino acids also decreased by $4.22-4.26 \%$ and 1.19 $-1.28 \%$.

It should be noted that the fat content in broiler meat was low, and was in the range of $2.04-1.84 \%$, versus $1.82 \%$ in the control. There were no significant differences from the control in terms of the content of crude ash. The conducted tasting evaluation did not reveal differences in the taste of meat and broth between the control and experimental groups.

Table 7. Chemical composition and amino acid content in the breast muscles of broiler chickens at the age of 35 days, $(\%)$ on air-dry basis.

\begin{tabular}{|l|c|c|c|}
\hline \multirow{2}{*}{ Indicator } & \multicolumn{3}{|c|}{ Group } \\
\cline { 2 - 4 } & 1 (c) & 2 & 3 \\
\hline Moisture & 73.69 & 72.48 & 71.16 \\
\hline crude protein & 84.79 & 80.22 & 79.77 \\
\hline crude fat & 1.82 & 2.04 & 1.84 \\
\hline crude ash & 4.24 & 4.00 & 4.13 \\
\hline Total amino acids, \% & $\mathbf{7 9 . 6 9}$ & $\mathbf{7 4 . 2 8}$ & $\mathbf{7 4 . 1 0}$ \\
\hline Non-essential amino acids, \% & $\mathbf{4 8 . 2 4}$ & $\mathbf{4 4 . 0 2}$ & $\mathbf{4 3 . 9 8}$ \\
\hline Essential amino acids & $\mathbf{3 1 . 4 5}$ & $\mathbf{3 0 . 2 6}$ & $\mathbf{3 0 . 1 2}$ \\
\hline
\end{tabular}

\section{Conclusion}

Thus, based on the data obtained, it can be assumed that in terms of bioavailability and productive effect on poultry, a new generation protein supplement can be used to partially replace feed of animal origin in compound feed for broilers. The rational level of its inclusion in compound feed for broiler chickens up to 21 days of age is $2 \%$ by weight of compound feed, and from 22nd day of age it is possible to increase the input level up to $4 \%$ by weight of compound feed.

\section{References}

1. N. T. Bingol, S. I.Dede, M. A. Karsli, Y. Değer, D. Kiliçalp Kılınç, S. Çetin, Brazilian Journal of Poultry Science, 18(4), 639 (2016)

2. G. Ciurescu, C. O. Pana, Romanian Biotechnological Letters, 22(1), 12204 (2017)

3. E. N. Andrianova, I. A. Egorov, E. N. Grigorieva, A. N. Shevyakov, V. V. Pronin, Agricultural Biology, 54(2), 326 (2019)

4. E. N. Andrianova, I. A. Egorov, V. V. Pronin, Agricultural Biology, 55(6), 1245 (2020) 
5. V. I. Fisinin, I. A. Egorov, Poultry feeding guide, 215 (2019)

6. I. A. Egorov, Unconventional feeds and additives, 391 (1992)

7. Diana N, Biotechnology and food of the future (2016) https://www.agroxxi.ru

8. I. A. Egorov, V. A. Manukyan, T. M. Okolelova, T. N. Lenkova, E. N. Andrianova, A. N. Shevyakov, T. V. Egorova, T. A. Egorova, E. Yu. Baykovskaya, N. N. Gogina, et al, Poultry feeding guide, 226 (2018)

9. E. S. Volobueva, Biotechnology for the production and use of functional additives based on microbial conversion of plant raw materials, 21 (2020) 